To cite this article: Özterlemez NT, Işık G, İnan G, Günaydın B. Aritmi ablasyon öyküsü olan gebenin spinal anestezi eşliğinde sezaryenle doğumunda anemi yönetimi. Turk J Clin Lab 2020; 2: 85-88.

- Olgu Sunumu

\title{
Aritmi ablasyon öyküsü olan gebenin spinal anestezi eşliğinde sezaryenle doğumunda anemi yönetimi
}

\section{Management of anemia in a parturient with an arrthymia ablation history for cesarean delivery under spinal anesthesia}

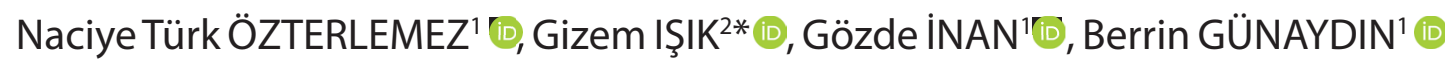 \\ ${ }^{1}$ Gazi Üniversitesi Tıp Fakültesi, Anesteziyoloji Anabilim Dalı, Ankara/TÜRKiYE \\ ${ }^{2}$ Gazi Üniversitesi Tıp Fakültesi, Kadın Hastalıkları ve Doğum Anabilim Dalı, Ankara/TÜRKIYE
}

\begin{abstract}
Öz
Preoperatif dönemde görülen aneminin perioperatif dönemde hastanede kalış süresinin uzaması, yoğun bakım ihtiyacı gibi birçok morbidite ve/veya mortaliteye yol açabilen perioperatif kan transfüzyonu için güçlü bir prediktör olduğu bilinmektedir. Burada radyo frekans aritmi ablasyon öyküsü olan anemik gebenin spinal anestezi altında elektif sezaryen sırasındaki doğum yönetimini sunmayı hedefledik. Güncel kanıtlar ışığında, cerrahi öncesinde anemi yönetimine göre, başarısız oral demir tedavisi nedeniyle halen anemik olan gebe olguda spinal anestezi altında sezaryenle doğum sırasında peroperatif tek doz IV demir tedavisi uygulayarak aritmi ablasyon öyküsü olan gebeye yaklaşımımızı sunduk.
\end{abstract}

Anahtar kelimeler: anemi; intravenöz demir tedavisi; sezaryen; peroperatif

\begin{abstract}
It has been known that preoperative anemia has been a strong predictor for perioperative blood transfusion that may lead to various types of adverse events including longer hospital stay, more ICU admission and morbidity and/or mortality. Hereby, we aimed to present management of an anemic parturient with radiofrequency arrythmiaablation history scheduled for elective cesarean delivery under spinal anesthesia. Based on the recent evidences related to preoperative anemia management, we preferred to correct failed oral iron treatment with a single dose of intravenous iron therapy perioperativelyin our parturient with iron deficiency anemia accordingly.
\end{abstract}

Keywords: anemia; intravenous iron treatment; cesearean delivery; peroperative

Corresponding Author*: Gizem Işık, Gazi Üniversitesi Tıp Fakültesi, Kadın Hastalıkları ve Doğum Anabilim Dalı, Ankara/TÜRKiYE E-mail: gizemgizem87@gmail.com

ORCID: 0000-0001-8810-3781

Gönderim: 26.02.2020 kabul: 02.03.2020

Doi: $10.18663 /$ tjcl.694672 


\section{Giriş}

Dünya sağlık örgütü (DSÖ) verilerine göre gebelerde en sık demir eksikliği anemisi (DEA) gözlenir ve sıklığı yaklaşık \%38.2'dir [1, 2]. DSÖ'ye göre gebelikte anemi için referans $\mathrm{Hb}$ değeri 1. trimesterde $<11 \mathrm{~g} / \mathrm{dL}, 2$. trimesterde $<10,5 \mathrm{~g} /$ $\mathrm{dL}$ ve 3 . trimesterde $<10 \mathrm{~g} / \mathrm{dL}$ 'dir[3]. Anemi taramasında genellikle $\mathrm{Hb}$ ve hematokrit testleri kullanılırken, demir eksikliği tanısında serum ferritin, demir düzeyleri ve transferin satürasyonu tercih edilir. Serum ferritininin sağlıklı yetişkinlerde $15 \mu \mathrm{g} / \mathrm{L}$ 'den düşük olması yetersiz demir rezervinin göstergesidir. Gebelerde ise fizyolojik olarak plazma hacminin genişlemesiyle göreceli olarak serum ferritinindeki düşme nedeniyle tartışmalı olmasına rağmen DSÖ bu değeri alt sınır kabul etmektedir $[4,5]$.

Eğer tedavi edilmezse DEA; düşük doğum ağırlığı, prematür doğum, anne-bebek ölümü, enfeksiyon riskinde artış gibi ciddi sonuçlara neden olabilir [1]. Maliyeti düşük demir ve folik asit tedavisiyle bu risklerin ve komplikasyonların azaltması için gebeliğin mümkün olan en erken döneminde anne adaylarına genelde $60 \mathrm{mg} / \mathrm{gün}$ elemental demir ve $400 \mu \mathrm{g}$ folik asit önerilmektedir [6]. Bir çok ülkenin antenatal bakım programlarında demir takviyesi yer almasına rağmen orta gelirli ülkelerdeki annelerin \%30'dan azının hamilelikte $\geq 3$ ay boyunca demir ve folik asit aldığını göstermektedir [7]. En önemlisi de cerrahiden çok kısa bir süre önce düzeltilen preoperatif aneminin per/postoperatif dönemde artan kan transfüzyonu gereksinimine bağlı hastanede kalış süresininuzaması, yoğun bakım ihtiyacını artması gibi birçok morbidite ve/veya mortaliteyi azaltabileceği bildirilmiştir [8]. Bu nedenle oral demir ve folik asit tedavisine rağmen halen anemik olan bu gebe olguda spinal anestezi altında sezaryenle doğum sırasında peroperatif tek doz iV demir tedavisi uygulayarak radyofrekans (RF) aritmi ablasyon öyküsü olan gebeye yaklaşımımızı sunmayı amaçladık.

\section{Olgu}

Term 29 yaşında ASA III multipar gebe (boy 161 cm, vücut ağırlığı 80 kg ve vücut kitle indeksi 30.9), mükerrer sezaryen endikasyonuyla elektif sezaryen için kabul edilmiştir. Olgunun tıbbi öyküsünden, 2007 yılında supraventriküler taşikardi (SVT) için RF ablasyon uygulandığı ve metoprolol süksinat (50 mg/gün) kullanılmakta olduğu ve ayrıca 18. gebelik haftasında oral demir ve folik asit başlandığı öğrenilmiştir. Gebenin 24. haftadaki Hb'nin11.6 g/dL olduğu için ikinci trimester gebe için anemi kabul edilmese de kurumun antenatal gebelik izlemine göre 60 mg/gün elemental demir ve $400 \mu \mathrm{g} / \mathrm{gün}$ folik asit önerilmiştir. Ancak tedaviye rağmen preoperatif değerlendirmede $\mathrm{Hb}$ 'nin9.8 g/
dL olması üzerine gebe sorgulandığında; başlanan oral demir preparatını mide bulantısı ve kabızlık nedeniyle kullanmadığı öğrenilmiştir. Bunun üzerine kesin anemi tanısı ve uygun tedaviyi planlayabilmek amacıyla acilen serum transferin, demir, demir bağlama kapasitesi ve retikülosit sayımı yapılmıştır. Serum transferin değeri 543,14 mg/dL (normal sınırlar:200-360 mg/dL), serum demiri 19.9 ug/dL (normal sınır:60-180 ug/dL), serum demir bağlama kapasitesi $763 \mu \mathrm{g} /$ $\mathrm{dL}$ (normal sınır: 155-355 $\mu \mathrm{g} / \mathrm{dL}$ ), retikülositoranı ise: $\% 1.58$ (normal sınır: \% 0.43-1.36) olarak saptanmıştır. Bu sonuçlarla DEA tanısı konularak gebeye intravenöz (IV) demir tedavisi planlanmıştır.

Anestezi yönetiminde gebeye önce preoperatif aspirasyon profilaksisi amacıyla metoklopramid ve ranitidin IV verilip, elektrokardiyografi (EKG), kalp hızı, non-invazif kan basıncı ve periferik oksijen satürasyon (SpO2) ile standart monitörizasyonu takiben oturur pozisyonda $12 \mathrm{mg}$ hiperbarik bupivakain +10 mcg fentanil $+100 \mu \mathrm{g}$ morfin ile spinal blok yapıldı. Yenidoğan 3380 gram erkek bebeğin 1. ve 5. dakika Apgar skorları sırasıyla 9 ve 10 idi. Umbilikal kord klemplendikten sonra gebeye bir damar yolundan 20 iÜ oksitosin/1000 mL Ringer laktat içinde IV infüzyonuna başlanırken, diğer damar yolundan da 500 mg demir (Ferriccarboxymaltose:FCM, Ferinject ${ }^{\circledR} 500$ mg flakon, Abdi İbrahim, İstanbul) $100 \mathrm{~mL}$ serum fizyolojik içinde 15 dakikada iV infüzyonla uygulandı. Operasyon yaklaşık yarım saatte sorunsuz bitti. Özgeçmişinde SVT nedeniyle RF ablasyon yapılmış olan gebede ameliyat boyunca kardiyak ritmde bir değişiklik gözlenmedi. Ameliyat sonunda yaklaşık olarak 750 $\mathrm{mL}$ kan kaybı olduğu tahmin edildi. Postoperatif 2.günde herhangi bir komplikasyona rastlanmadan taburcu edildi. Postpartum 2.ay kontrolünde Hb14.1 g/dL idi. Preoperatif (IV demir infüzyonu öncesi) ve postoperatif 40. gündeki tam kan sayımı değerleri sunulmuştur (tablo 1).

\begin{tabular}{|l|l|l|}
\hline \multicolumn{3}{|c|}{ Tablo 1. Preoperatif ve postoperatif 40. gün tam kan sayımı değerleri } \\
\hline & Preoperatif & Postoperatif 40. gün \\
\hline Hemoglobin (12-14 g/dL) & 9,8 & 14,1 \\
\hline Hematokrit $(\% 36,6-44)$ & 31,7 & 42 \\
\hline MCV (82,9-98 fL) & 73,5 & 78,8 \\
\hline MCH (27-32,3 Pg) & 22,7 & 26,5 \\
\hline
\end{tabular}

\section{Tartışma}

Başarısız oral demir tedavisi nedeniyle halen anemik ve aritmi ablasyon öyküsü olan gebe olguda spinal anestezi altında sezaryenle doğum sırasında peroperatif tek doz iV demir tedavisi komplikasyonsuz başarıyla uygulandı.

DSÖ, üreme çağındaki kadınlarda anemiyi 2025 yılına kadar 
\%50 azaltmayı küresel beslenme hedeflerinden biri olarak tanımlamıştır [9]. Gebelikte eritrosit kütlesindeki artış (ek $450 \mathrm{mg}$ demir), fetal ve plasental dokulardaki artış (300 mg demir), artmış bazal maternal gereksinimler (yaklaşık 240mg demir) ve doğumdaki kan kaybı (yaklaşık 250mg demir) [10]. Tüm bu süreçte kadının ihtiyacı olan ek demir yaklaşık 1 gramdır [11].Birçok gebe kadında maternal hemoraji, sepsis, bebeklerde düşük doğum ağırlığı, erken doğum, psikomotor gelişme geriliği gibi komplikasyonlarla DEA'nın ilişkisi tanımlanmıştır.Bu kanıtlar ışığında DSÖ tarafından kadınlara demir replasmanı gerektiği konusunda bir kılavuz yayınlamıştır [12]. Bizim olgumuzda feto-maternal hiçbir komplikasyon izlenmedi.

Demir eksikliğini tanısında serum ferritini eğer herhangi başka bir patoloji yoksa direkt depo demirini gösterir.Demir taşıma molekülü olan transferrinin ölçümü de plazmadaki demir miktarı yansıtır. Normal referans kadınlarda\%12-45'tir. İzole DEA tanısında hipokromik mikrositer eritrositlerin yüzdesi kullanılırken, retikülosit hemoglobini (Ret $\mathrm{He}$ ) gibi diğer belirteçler inflamatuar durumlarında teşhise yardımcı olur [3]. Bizim olgumuzda hipokrom mikrositer izole DEA anemisi vardı.

Yüksek seviyelerde demir veya inflamasyona cevap olarak üretilen peptid yapıda bir hormon olan hepsidin, demir miktarının belirlenmesinde oldukça faydalıdır. Artan hepsidin, demirin enteroksit veya makrofajlarda kalarak eritroblast gelişmesine neden olacaktır. Oysa hamileliktedemir için yüksek talep nedeniyle hepsidin düşerek, 3.trimesterde saptanamaz (13). Bununla birlikte serum hepsidini, demir alımından sonra hızla yükselir [14] ve DEA'lı kadınlarda serum hepsidini normale dönene kadar demir emiliminin seri dozlarda veya oral demir sülfatla azaldığı doğrulanmıştır[15]. Her ne kadar rutin serum hepsidin ölçümü yapılmasa da dünyada hepsidin harmonizasyon çalışmaları sürdürülmektedir [16].

Son meta-analizlerde $[17,18]$ anemik gebelerde doğumdan 4 hafta önce yapılan oral ile iV demir tedavisinin etkinliği karşılaştırıldığında; gerek maternal $\mathrm{Hb}$ ve ferritindeki artışın gerekse hedef $\mathrm{Hb}$ konsantrasyonuna ulaşmada iV demir tedavisinin daha başarılı olduğu kanıtlanmıştır. Tek doz veya yüksek doz iV demir preparatlarıla (FCM veya izomaltosid) tedavinin postpartum anemi veya şiddetli uterin kanamalardaki etkinliği randomize kontrollü araştırmalarda gösterilmiştir [19, 20]. Postpartum hemorajisi olan (>1000 mL kanama ve $\mathrm{Hb}$ 5.6$8.1 \mathrm{~g} / \mathrm{dL}$ ) kadınlara rastgele iV tek doz $1500 \mathrm{mg}$ izomaltosid veya eritrosit konsantresi verildiğinde;iV demirin ilk haftada retikülositozu ve 3-12 haftalarda da Hb'ini daha çok artırdığı gösterilmiştir (19). Hb 11 g/dL olan DEA tanısı konmuş şiddetli adet kanamalı kadınlarda yapılan bir araştırmada yüksek doz IV FCM (her hafta 1000 mg/15 dk'da hesaplanan doza ulaşana dek) veya 6 hafta oral demir (günde 3 kez 325 mg) tedavisi sonrasında; IV demirin aneminin düzeltilmesinde, demir depolarının dolmasında ve hayat kalitesinin iyileştirilmesinde daha etkin olduğu gösterilmiştir [20]. Bu çalışmalar doğrultusunda gebe olgumuzda umbilikal kord klemplendikten hemen sonra tek doz IV 500 mg FCM uyguladık.

Avrupa rehberine göre, cerrahi kanama riski olan hastalar cerrahiden 3 ile 8 hafta önce değerlendirilmeli eğer anemi varsa, etyolojik neden (demir eksikliği, böbrek yetmezliği veya inflamasyon) belirlenmelidir. Güncel kanıtlar; yetişkinlerde ve çocuklarda preoperatif anemi varlığında perioperatif kan transfüzyonunun riskinin yüksek olduğunu göstermektedir [21]. Bu nedenle kliniğimizde özellikle doğumlardan önce demir eksikliği anemisini mümkünse preoperatif yoksa perioperatif iV demir ile düzeltmeyi tercih etmekteyiz

Froesler ve ark [22], $\leq \mathrm{Hb} 11 \mathrm{~g} / \mathrm{dL}$ olan 271 gebede sezaryen ile doğumdan 42 gün önce rasgele ya oral ya da IV demir (sükroz) uyguladıklarında iki tedavinin de anemiyi düzeltmede etkili olduğunu ancak IV demirle belirgin olarak daha hızlı düzelme görmüştür. Çalışmada yalnızca 1 olgu, ilk IV demir uygulamada gelişen aritmi nedeniyle analizden çıkarılmıştır. Bizim olgumuzda RF ablasyon öyküsü bulunması nedeniyle EKG monitörizasyonu ve ritm takibi çok dikkatli yapıldı ve dekstran içermeyen bir demir preparatı olan FCM'nin IV infüzyonuna bağlı herhangi bir advers etki izlenmedi.

\section{Sonuç}

Gebeliğin geç dönemlerinde oral demir tedavisi ile başarısız olunmuş cerrahi gerektiren olgularda perioperatif IV demir tedavisi, DEA'nın hızlı ve güvenli düzeltilmesinde akılcı bir tercih olarak görülmektedir.

*Hastadan aydınlatılmış onam belgesi alınmıştır.

\section{Kaynaklar}

1. Pena-Rosas JP, De-Regil LM, Gomez Malave H, Flores-Urrutia MC, Dowswell T. Intermittent oral iron supplementation during pregnancy. Cochrane Database Syst Rev 2012; 11: 9997.

2. Stevens GA, Finucane MM, De-Regil LM et al. Global, regional, and national trends in haemoglobin concentration and prevalence of total and severe anaemia in children and pregnant and non-pregnant women for 1995-2011: a systematic analysis of population-representative data. Lancet Glob Health 2013; 1: e16-25. 
3. Roy NBA, Pavord S. The management of anaemia and haematinic deficiencies in pregnancy and post-partum. Transfus Med 2018; 28: 107-16.

4. Organization WH. Serum ferritin concentrations for the assessment of iron status and iron deficiency in populations. World Health Organization; 2011.

5. Garcia-Casal MN, Pena-Rosas JP, Pasricha SR. Rethinking ferritin cutoffs for iron deficiency and overload. Lancet Haematol 2014; 1: 92-94.

6. Organization WH. WHO recommendations on antenatal care for a positive pregnancy experience: World Health Organization; 2016.

7. Boerma T, Requejo J, Victora CG et al. Countdown to 2030: tracking progress towards universal coverage for reproductive, maternal, newborn, and child health. The Lancet 2018; 391: $1538-48$

8. Spahn DR, Schoenrath F, Spahn GH et al. Effect of ultra-shortterm treatment of patients with iron deficiency or anaemia undergoing cardiac surgery: a prospective randomised trial. Lancet 2019; 393:2201-12.

9. Targets WGN. 2025: anaemia policy brief. Geneva: World Health Organization. 2014.

10. De Leeuw NK, Lowenstein L, Hsieh YS. Iron deficiency and hydremia in normal pregnancy. Medicine (Baltimore) 1966; 45: 291-315

11. Bothwell TH. Iron requirements in pregnancy and strategies to meet them. Am J Clin Nutr 2000; 72: 257-64.

12. Guideline W. Daily iron and folic acid supplementation in pregnant women. Geneva: World Health Organization 2012; 27.

13. van Santen $S$, de Mast Q, Swinkels DW, van der Ven AJ. The iron link between malaria and invasive non-typhoid Salmonella infections. Trends Parasitol 2013; $29: 220-27$.

14. Ganz T. Iron homeostasis: fitting the puzzle pieces together. Cell Metab. 2008; 7: 288-90.
15. Moretti D, Goede JS, Zeder C et al. Oral iron supplements increase hepcidin and decrease iron absorption from daily or twice-daily doses in iron-depleted young women. Blood 2015; 126: 1981-89.

16. van der Vorm LN, Hendriks JC, Laarakkers CM et al. Toward Worldwide Hepcidin Assay Harmonization: Identification of a Commutable Secondary Reference Material. Clin Chem 2016; 62: 993-1001.

17. Lewkowitz AK, Gupta A, Simon L et al. Intravenous compared with oral iron for the treatment of iron-deficiency anemia in pregnancy: a systematic review and meta-analysis. J Perinatol 2019; 39: 519-32.

18. Govindappagari S, Burwick RM. Treatment of Iron Deficiency Anemia in Pregnancy with Intravenous versus Oral Iron: Systematic Review and Meta-Analysis. Am J Perinatol. 2019; 36: 366-76.

19. Holm C, Thomsen LL, Norgaard A, Langhoff-Roos J. Single-dose intravenous iron infusion or oral iron for treatment of fatigue after postpartum haemorrhage: a randomized controlled trial. Vox Sang 2017; 112: 219-28.

20. Van Wyck DB, Mangione A, Morrison J, Hadley PE, Jehle JA, Goodnough LT. Large-dose intravenous ferric carboxymaltose injection for iron deficiency anemia in heavy uterine bleeding: a randomized, controlled trial. Transfusion 2009; 49: 2719-28.

21. Kozek-Langenecker SA, Ahmed AB, Afshari A et al. Management of severe perioperative bleeding: guidelines from the European Society of Anaesthesiology: First update 2016. Eur J Anaesthesiol 2017; 34: 332-95.

22. Froessler B, Cocchiaro C, Saadat-Gilani K, Hodyl N, Dekker G. Intravenous iron sucrose versus oral iron ferrous sulfate for antenatal and postpartum iron deficiency anemia: a randomized trial. J Matern Fetal Neonatal Med 2013; 26: 654-59. 